\title{
Efektivitas problem-based learning ditinjau dari keterampilan pemecahan masalah dan kemandirian belajar matematis
}

\author{
Yuli Kurniyawati ${ }^{1}$, Ali Mahmudi ${ }^{2 *}$ Endang Wahyuningrum ${ }^{3}$ \\ ${ }^{1}$ SMP Negeri 1 Ngadirejo. Demangan, Ngadirejo, Temanggung, Jawa Tengah 56255, Indonesia \\ 2 Jurusan Pendidikan Matematika, Fakultas Matematika dan Ilmu Pengetahuan Alam, Universitas Negeri \\ Yogyakarta. Jalan Colombo No. 1, Yogyakarta 55281, Indonesia \\ ${ }^{3}$ Universitas Terbuka. Jalan Cabe Raya, Pondok Cabe, Pamulang, Tangerang Selatan 15418, Banten - Indonesia \\ E-mail: alimahmudi@uny.ac.id \\ * Corresponding Author
}

\section{ARTICLE INFO}

\section{Article history}

Received: 5 Sept. 2019;

Revised: 6 Sept. 2019;

Accepted: 11 Sept. 2019

\section{Keywords}

problem-based learning; keterampilan pemecahan masalah; kemandirian belajar; problem-based learning; mathematical problem-solving skills; selfregulated learning

\begin{abstract}
Penelitian ini bertujuan untuk mendeskripsikan efektifitas problem-based learning ditinjau dari keterampilan pemecahan masalah dan kemandirian belajar matematis. Penelitian ini merupakan penelitian Quasi Experimental dengan populasi siswa kelas VIII SMP Negeri 1 Ngadirejo Temanggung tahun pelajaran 2017/2018. Pengambilan sampel dilakukan secara acak dengan mengambil 3 kelas dari 7 kelas yang ada, dan terpilih kelas VIII A sebagai kelas ujicoba, kelas VIIIB sebagai kelas eksperimen, dan kelas VIIIC sebagai kelas kontrol. Instrumen penelitian yang digunakan adalah tes keterampilan pemecahan masalah matematis dan skala kemandirian belajar matematis. Hasil penelitian menunjukkan bahwa problem-based learning efektif ditinjau dari keterampilan pemecahan dan kemandirian belajar matematis. Terdapat perbedaan efektivitas antara problem-based learning dan pembelajaran konvensional ditinjau dari keterampilan pemecahan masalah dan kemandirian belajar matematis. Terdapat hubungan signifikan antara keterampilan pemecahan masalah dan kemandirian belajar matematis.
\end{abstract}

This study aims to determine the effectiveness of problem-based learning in terms of mathematical problem-solving skills and self-regulated. This study is quasi-experimental with a population of students of grade VIII SMP Negeri 1 Ngadirejo Temanggung academic year 2017/2018. The sampling was done randomly by taking 3 of 7 classes, and the elected class was VIII A, VIIIB, and VIIIC. Then, the three classes were randomized to determine the tryout class, control, and experimental class. Class VIIIB was selected as an experimental class, VIIIC as a control class and VIIIA as a tryout class. The instrument used was the test of mathematical problem-solving skills, the scale of self-regulated learning and observation sheet of learning implementation. The results of this study showed that problem-based learning is effective in terms of mathematical problem-solving skills and self-regulated learning. There is a difference in effectiveness between problem-based learning and conventional learning in terms of mathematical problem-solving skills and self-regulated learning. There is a significant relationship between mathematical problem-solving skills and self-regulated learning.

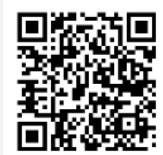

This is an open access article under the CC-BY-SA license.

How to Cite: Kurniyawati, Y., Mahmudi, A., \& Wahyuningrum, E. (2019). Efektivitas problem-based learning ditinjau dari keterampilan pemecahan masalah dan kemandirian belajar matematis. Jurnal Riset Pendidikan Matematika, 6(1), 118-129. doi:https://doi.org/10.21831/jrpm.v6i1.26985 


\section{PENDAHULUAN}

Pendidikan memiliki peranan penting bagi kemajuan suatu bangsa. Melalui pendidikan dapat ditanamkan karakter, nilai-nilai sikap, dan kompetensi yang diperlukan siswa. Kemajuan suatu bangsa dapat dilihat dari seberapa maju sektor pendidikannya. Oleh karena itu, mutu pendidikan sangat penting untuk ditingkatkan serta menjadi tanggung jawab semua pihak. Untuk meningkatkan mutu pendidikan perlu adanya suatu upaya pembelajaran yang berkualitas. Pembelajaran yang berkualitas dapat diciptakan dengan adanya proses pembelajaran yang memperhatikan tujuan, materi, model pembelajaran, karakteristik siswa, dan media pembelajaran. Berbagai hal tersebut menjadi fokus perhatian untuk semua mata pelajaran, termasuk dalam pembelajaran matematika.

Pembelajaran matematika sebagai bagian dari proses pendidikan di sekolah mempunyai peranan penting dalam peningkatan kompetensi peserta didik. Hal ini sesuai dengan Peraturan Menteri Pendidikan dan Kebudayaan Nomor 21 Tahun 2016 tentang standar isi bahwa mata pelajaran matematika pada tingkat pendidikan dasar diberikan agar siswa mempunyai kompetensi mampu menunjukkan sikap logis, kritis, analitis, cermat dan teliti, bertanggung jawab, dan tidak mudah menyerah dalam memecahkan masalah (Kementerian Pendidikan dan Kebudayaan Republik Indonesia, 2016). Berdasarkan standar isi tersebut, terlihat bahwa kemampuan pemecahan masalah merupakan bagian dari pembelajaran matematika yang sangat penting.

Pentingnya pemecahan masalah (problem solving) juga dinyatakan oleh NCTM (2000), "Problem solving is an integral part of all mathematics learning". Hal tersebut menegaskan mengenai pentingnya pemecahan masalah yang merupakan bagian tak terpisahkan dalam pembelajaran matematika, sehingga hal tersebut tidak boleh dilepaskan dari pembelajaran matematika. Sugiman (2013) juga mengemukakan bahwa kemampuan problem solving merupakan core dari pembelajaran matematika mulai dari jenjang dasar hingga menengah atas sebagaimana tuntutan dari Kurikulum 2006. Dari kajian beberapa pendapat tersebut dapat disimpulkan bahwa pemecahan masalah menempati posisi yang sangat penting dan merupakan inti dari kurikulum dan pembelajaran matematika di sekolah.

Kemampuan pemecahan masalah sangat penting untuk dikuasai siswa, akan tetapi kemampuan pemecahan masalah siswa di Indonesia masih rendah. Hal ini dibuktikan oleh hasil tes yang dilakukan oleh dua studi Internasional. Berdasarkan hasil survei Programme for International Student Assesment (PISA) pada tahun 2012 diperoleh bahwa Indonesia berada pada urutan 64 dari 65 negara peserta (OECD, 2014). Berdasarkan hasil TIMSS pada tahun 2011, Indonesia menempati urutak ke-38 dari 42 negara peserta dengan rerata skor 386, sedangkan rerata internasional 500 (Kementerian Pendidikan dan Kebudayaan Republik Indonesia, 2011). Data dari Pusat Penilaian Pendidikan (Puspendik, 2015) juga menunjukkan bahwa dalam ujian nasional untuk soal dengan indikator pemecahan masalah mempunyai daya serap yang lebih rendah dibandingkan dengan soal yang bukan pemecahan masalah. Untuk tingkat propinsi Jawa Tengah persentase daya serap yang kurang dari $50 \%$ diantaranya pada pemecahan masalah untuk materi bilangan dan deret $(37,41 \%)$, fungsi $(41,33 \%)$, persamaan/pertidaksamaan linear satu variabel $(43,40 \%)$, dan sistem persamaan linear dua variabel $(47,40 \%)$ (Puspendik, 2015). Hal ini menjadi salah satu indikasi bahwa siswa mengalami kesulitan pada soal pemecahan masalah.

Selain kesulitan dalam pemecahan masalah, seringkali siswa juga mengalami kesulitan belajar matematika, diantaranya pada materi Sistem Persamamaan Linier Dua Variabel (SPLDV). Kesulitan ini ditandai dengan kesalahan-kesalahan yang dilakukan siswa dalam menyelesaikan soal cerita pada materi SPLDV. Hasil penelitian Wijaya dan Marsriyah (2013) menyimpulkan bahwa kesalahan siswa dalam menyelesaikan soal cerita pada materi SPLDV diantaranya: (1) kesalahan dalam memahami soal (tidak lengkap menuliskan apa yang diketahui); (2) kesalahan membuat model matematika (tidak menuliskan pemisalan yang dipakai pada pembuatan model, salah dalam menuliskan pemisalan, dan model matematika yang dibuat tidak sesuai dengan permasalahan); (3) kesalahan menyelesaikan model; dan (4) kesalahan dalam menyatakan jawaban akhir. Kesalahan-kesalahan yang masih terjadi tersebut menjadi indikasi kuat bahwa siswa masih mengalami kesulitan belajar matematika.

Berdasarkan hasil observasi di SMP Negeri 1 Ngadirejo Temanggung, diperoleh fakta bahwa kemampuan pemecahan masalah matematis siswa belum maksimal terutama pada materi SPLDV. Nilai ulangan materi SPLDV pada tahun 2018 menunjukkan hasil yang kurang memuaskan, yaitu belum memenuhi ketuntasan secara klasikal sebesar 85\% dengan KKM untuk mata pelajaran 
matematika di SMP Negeri 1 Ngadirejo Temanggung adalah 75. Banyak siswa tuntas hanya 21 orang dari 32 siswa, jika dipersentase ketuntasannya hanya 65,6\%, dan rata-rata yang dicapai hanya 66,01. Disamping belum mencapai KKM, ditemukan banyak siswa belum dapat mengidentifikasi dengan tepat apa yang diketahui dari soal, banyak siswa belum tepat dalam menuliskan model matematika, juga banyak siswa yang salah dalam menginterpretasikan/memaknai hasil yang didapatkan.

Kenyataan tersebut menunjukkan bahwa sampai saat ini masih ditemukan kesulitan-kesulitan yang dialami siswa dalam mempelajari matematika, terutama untuk soal pemecahan masalah. Selain itu, dari hasil observasi diketahui pula bahwa guru masih menggunakan model pembelajaran konvensional, yakni guru menyampaikan materi melalui ceramah, latihan soal, kemudian pemberian tugas. Pembelajaran matematika diarahkan kepada kemampuan peserta didik untuk menghafal, mengingat, menimbun informasi ataupun rumus-rumus dan belum diarahkan untuk meningkatkan kemampuan memahami, mengolah informasi yang diterimanya serta memecahkan masalah yang ada untuk dihubungkan dengan kehidupan sehari-hari.

Selain kemampuan pemecahan masalah, tidak kalah penting untuk dikembangkan pada siswa adalah kemandirian belajar. Hal ini sesuai dengan yang diamanatkan oleh Undang-Undang Sistem Pendidikan Nasional (Presiden Republik Indonesia, 2003) bahwa salah satu tujuan pendidikan nasional, selain untuk mengembangkan potensi peserta didik agar menjadi manusia yang beriman dan bertakwa kepada Tuhan Yang Esa, juga bertujuan agar peserta didik menjadi pribadi yang mandiri. Dengan demikian, selama proses pembelajaran di sekolah diharapkan siswa ikut berpartisipasi aktif, bukan hanya guru yang aktif. Siswa yang aktif dan mandiri selama pembelajaran diharapkan dapat memahami pelajaran yang diikuti, sehingga pada akhirnya dapat menyelesaikan soal matematika dengan benar.

Berdasarkan hasil observasi di kelas VIII D SMP Negeri 1 Ngadirejo Temanggung, diperoleh informasi bahwa pembelajaran matematika di kelas cenderung bersifat berpusat pada guru (teacher centered). Pembelajaran yang bersifat searah ini membuat siswa bergantung pada guru, sehingga selama proses belajar mengajar siswa cenderung pasif. Siswa belum aktif dalam menggunakan berbagai sumber belajar dan belum aktif dalam diskusi kelompok. Siswa juga hanya mendengarkan, mencatat materi, kemudian siswa diinstruksikan untuk mengerjakan latihan-latihan soal dengan rumus yang diberikan guru, tanpa tahu akan tujuan dan manfaat yang akan mereka peroleh setelah proses pembelajaran. Kondisi yang demikian berdampak pada kurangnya kemandirian siswa dalam pembelajaran matematika.

Terkait belum optimalnya kemampuan pemecahan masalah dan kemandirian belajar siswa, maka perlu pemilihan model pembelajaran yang dapat meningkatkan kemampuan pemecahan masalah matematis dan kemandirian belajar, salah satunya yaitu dengan Problem-Based Learning (PBL). Barrows (Barrett, 2005) menjelaskan bahwa "Problem-Based Learning is the learning that results from the process of working toward the understanding of a resolution of a problem. The problem is ecountered first in the learning process". Hal ini menunjukkan bahwa pembelajaran berbasis masalah adalah suatu pembelajaran yang dihasilkan dari proses bekerja menuju pemahaman masalah, dimana masalah diberikan pada awal proses pembelajaran. Fogarty (Chen, 2013) menyatakan bahwa " $P B L$ as a course model that focuses on real world problems", yang artinya PBL sebagai model pembelajaran yang fokus pada masalah dunia nyata. Arends (2008) dan Imandala, Li, \& Supriyadi (2019) mengemukakan bahwa $P B L$ membantu siswa untuk mengembangkan keterampilan berpikir dan ketrampilan mengatasi masalah, serta memfasilitasi siswa untuk menjadi pelajar yang aktif dan mandiri.

Terdapat beberapa keuntungan ketika menggunakan PBL, seperti yang dikemukakan Uden dan Beaumont (Suprihatiningrum, 2012, p.222) yang menyatakan beberapa keuntungan yang dapat diamati dari siswa yang belajar dengan menggunakan pendekatan PBL diantaranya mampu mengingat dengan lebih baik informasi dan pengetahuannya; mengembangkan kemampuan pemecahan masalah, berpikir kritis dan keterampilan komunikasi; meningkatkan motivasi dan mengembangkan berbagai strategi belajar. Dari pendapat tersebut dan pendapat-pendapat ahli seblumnya, dapat disimpulkan bahwa PBL adalah model pembelajaran yang menyajikan masalahmasalah di tahap awal pembelajaran yaitu pada tahap orientasi siswa pada masalah. Dengan demikian siswa akan terbisa untuk menyelesaikan masalah, dimana menyelesaikan masalah sesuai rencana merupakan bagian dari kemampuan pemecahan masalah matematis. Disamping itu PBL juga dapat meningkatkan kemandirian belajar siswa.

Terkait dengan penerapan PBL, beberapa penelitian telah dilakukan untuk mengungkap dampak PBL terhadap hasil pembelajaran. Hasil penelitian Setiawan, Waluya, dan Mashuri (2014) 
menunjukkan bahwa aktivitas siswa yang ditimbulkan oleh PBL berpengaruh positif terhadap kemampuan pemecahan masalah siswa. Hasil penelitian Hima (2016) melaporkan bahwa PBL juga dapat meningkatkan kemampuan komunikasi matematis siswa. Hasil-hasil penelitian tersebut mengindikasikan bahwa PBL memberikan kontribusi positif terhadap hasil belajar siswa, namun penelitian-penelitian tersebut belum menyelidiki terkait dampak PBL terhadap kemampuan pemecahan masalah dan kemandirian belajar siswa. Untuk itu, penelitian ini bertujuan untuk mendeskripsikan efektifitas problem-based learning ditinjau dari keterampilan pemecahan masalah dan kemandirian belajar matematis.

\section{METODE}

Penelitian ini merupakan quasi-experimental. Populasi dalam penelitian ini adalah seluruh siswa kelas VIII SMP Negeri 1 Ngadirejo Temanggung tahun pelajaran 2017/2018 sebanyak 7 kelas. Pengambilan sampel dilakukan acak secara kelompok, dimana kelompok yang diambil berupa kelas yaitu dengan mengambil 3 kelas dari 7 kelas yang ada, dan terpilih kelas VIII A, VIII B, dan VIII C sebagai subjek penelitian. Dari ketiga kelas tersebut, kemudian diacak kembali, sehingga kelas VIII B terpilih sebagai kelas eksperimen, kelas VIII C sebagai kelas kontrol, dan kelas VIII A sebagai kelas ujicoba. Kelas eksperimen diberikan perlakuan berupa pembelajaran menggunakan model PBL. Kelas kontrol diberikan perlakuan berupa pembelajaran langsung (konvensional). Adapun kelas ujicoba digunakan untuk ujicoba pembelajaran dengan menggunakan perangkat PBL yang terdiri dari Rencana Pelaksanaan Pembelajaran (RPP), Lembar Kegiatan Siswa (LKS), dan instrumen penelitian. Ujicoba pembelajaran dimaksudkan untuk mengetahui apakah PBL dengan RPP yang telah disusun dapat dilaksanakan, juga untuk mengetahui apakah LKS yang telah disusun dapat digunakan. Berdasarkan hasil uji pembelajaran diketahui bahwa model pembelajaran PBL dengan RPP dan LKS yang telah disusun dapat dilaksanakan, dengan ada beberapa revisi pada LKS. Setelah uji coba pembelajaran siswa diberi tes akhir dan angket yang merupakan ujicoba instrumen.

Instrumen dalam penelitian ini terdiri dari tes keterampilan pemecahan masalah dan skala kemandirian belajar matematis. Tes keterampilan pemecahan masalah berbentuk uraian. Sebelum diujikan kedua instrumen tersebut divalidasi dengan meminta pendapat dan masukan dari ahli. Setelah instrumen diperbaiki sesuai dengan saran validator, kemudian dilakukan ujicoba terbatas untuk memperoleh informasi terhadap keterbacaan instrumen. Setelah uji terbatas kemudian dilakukan ujicoba pembelajaran dan uji coba instrumen. Reliabilitas tes keterampilan pemecahan masalah maupun skala kemandirian belajar matematis diestimasi menggunakan rumus Kuder-Richarson dengan KR-20. Dari hasil perhitungan diperoleh koefisien alpha untuk instrumen tes kemampuan pemecahan masalah sebesar 0,857 dan 0,889 untuk skala kemandirian belajar matematis.

Data hasil skor pretest dan posttest dari tes keterampilan pemecahan masalah dan skala kemandirian belajar matematis diambil setelah dilakukan pembelajaran. Data posttest keterampilan pemecahan masalah matematis digunakan untuk melihat efektivitas pembelajaran dengan PBL ditinjau dari keterampilan pemecahan masalah matematis, sedangkan skala kemandirian digunakan untuk melihat efektivitas PBL ditinjau dari kemandirian belajar matematis.

Analisis statistik uji inferensial dilakukan untuk menguji kesamaan mean kedua kelas (eksperimen vs. kontrol) dan menguji hipotesis-hipotesis yang diajukan dalam penelitian. Hipotesis-hipotesis yang diajukan pada penelitian ini mengarah pada tujuan untuk membandingkan keefektifan PBL dengan pembelajaran konvensional ditinjau dari keterampilan pemecahan masalah dan kemandirian belajar matematis. Pembelajaran dengan pendekatan PBL maupun pembelajaran konvensional dikatakan efektif ditinjau dari keterampilan pemecahan masalah matematis apabila rata-rata skor yang diperoleh lebih dari KKM, yaitu 75, dan lebih dari 85\% nilainya lebih dari KKM. Secara statistik, efektivitas tersebut diuji dengan one sample t-test untuk mengetahui apakah rata-rata secara statistik signifikan lebih dari KKM. PBL maupun pembelajaran konvensional dikatakan efektif ditinjau dari kemandirian belajar matematis apabila rata-rata skor kemandirian berada pada katagori tinggi (>90) dan lebih dari $85 \%$ skor kemandirian berada pada katagori tinggi. Secara statistik efektivitas tersebut diuji dengan One sample $T$ test untuk mengetahui apakah rata-rata skor kemandirian belajar tersebut sifnifikan lebih dari 90 .

Analisis korelasi dilakukan untuk melihat signifikansi hubungan antara kedua variabel terikat (kemampuan pemecahan masalah dan kemandirian belajar matematis). Jika terdapat korelasi signifikan diantara kedua variabel terikat tersebut, maka dapat dilakukan uji Multivariat Analysis of Variance 
(MANOVA). Uji MANOVA digunakan untuk menguji kesamaan vektor rata-rata kemampuan pemecahan masalah dan kemandirian belajar pada kelompok eksperimen (PBL) dan kelompok kontrol (konvensional). Semua uji statistik dalam penelitian ini dilakukanpada taraf signifikansi $5 \%(\alpha=0,05)$.

\section{HASIL DAN PEMBAHASAN}

\section{Deskripsi Keterampilan Pemecahan Masalah dan Kemandirian Belajar Matematis Siswa}

Keterampilan pemecahan masalah matematis dideskripsikan berdasarkan perolehan nilai pretest dan posttest yang terdiri atas 5 soal uraian. Tabel 1 menyajikan deskripsi data tentang keterampilan pemecahan masalah matematis dari penyelesaian soal uraian pada materi SPLDV pada kelas eksperimen dan kelas kontrol.

Tabel 1. Deskripsi Keterampilan Pemecahan Masalah

\begin{tabular}{lcccc}
\hline \multirow{2}{*}{ Deskripsi } & \multicolumn{2}{c}{ Pretest } & \multicolumn{2}{c}{ Posttest } \\
\cline { 2 - 5 } & Eksperimen & Kontrol & Eksperimen & Kontrol \\
\hline Nilai Minimum & 0 & 0 & 57 & 34 \\
Nilai Maksimum & 33 & 40 & 100 & 100 \\
Nilai Maksimum ideal & 100 & 100 & 100 & 100 \\
Rata-rata & 11,01 & 11,74 & 84,12 & 77,27 \\
Simpangan baku & 7,48 & 8,95 & 12,41 & 18,89 \\
Banyak siswa & 31 & 31 & 31 & 31 \\
\hline
\end{tabular}

Pada Tabel 1 tampak bahwa rata-rata keterampilan pemecahan masalah awal (pretest) siswa kelas eksperimen dan kelas kontrol tidak jauh berbeda. Hal tersebut menunjukkan bahwa kemampuan awal kedua kelas tersebut secara deskriptif sama relatif sama. Pada Tabel 1 juga dapat dilihat bahwa untuk hasil posttest, rerata keterampilan pemecahan masalah matematis siswa pada kelas eksperimen lebih tinggi dari rerata siswa pada kelas kontrol. Hal tersebut menunjukkan bahwa kemampauan pemecahan masalah siswa setelah diterapkannya PBL lebih baik dibandingkan siswa yang belajar dengan pendekatan konvensional.

Tabel 2 menyajikan perbandingan distribusi jumlah siswa berdasarkan kategori keterampilan pemecahan masalah matematis pada kelas eksperimen dan kontrol setelah diberi perlakuan (PBL vs. konvensional).

Tabel 2. Sebaran Kemampuan Pemecahan Masalah Siwa

\begin{tabular}{|c|c|c|}
\hline \multirow{2}{*}{ Kategori } & \multicolumn{2}{|c|}{ Banyak Siswa } \\
\hline & Eksperimen & Kontrol \\
\hline Sangat tinggi & 13 & 11 \\
\hline Tinggi & 14 & 9 \\
\hline Sedang & 4 & 5 \\
\hline Rendah & - & 6 \\
\hline Total & 31 & 31 \\
\hline
\end{tabular}

Berdasarkan Tabel 2 terlihat bahwa pada kelas eksperimen tidak terdapat siswa dengan kategori keterampilan pemecahan masalah yang rendah. Jumlah siswa pada kategori kemampuan pemecahan masalah sangat tinggi, tinggi, dan sedang pada kelas eksperimen lebih banyak dari kelas kontrol.

Adapun rata-rata skor dari setiap aspek keterampilan pemecahan masalah matematis pada kelas eksperimen dan kelas kontrol disajikan pada Tabel 3.

Tabel 3. Rata-Rata Skor untuk Setiap Aspek Kemampuan Pemecahan Masalah Matematis

\begin{tabular}{lccc}
\hline \multicolumn{1}{c}{ Aspek } & Skor Ideal & Eksperimen & Kontrol \\
\hline Memahami masalah: & & & \\
- Mengidentifikasi apa yang diketahui & 2 & $1,88(94,00 \%)$ & $1,78(89,00 \%)$ \\
- Mengidentifikasi apa yang ditanyakan & 2 & $1,73(86,50 \%)$ & $1,68(84,00 \%)$ \\
Merencanakan penyelesaian & 3 & $2,81(93,66 \%)$ & $2,32(77,33 \%)$ \\
Menyelesaikan masalah sesuai rencana & 3 & $2,68(89,33 \%)$ & $2,17(72,33 \%)$ \\
Interpretasi & 3 & $2,23(74,33 \%)$ & $2,06(68,66 \%)$ \\
\hline
\end{tabular}


Tabel 3 menunjukkan bahwa siswa pada kelas eksperimen yang mengikuti pembelajaran PBL memiliki skor rerata kemampuan pemecahan masalah matematis lebih tinggi pada setiap aspeknya dibandingkan siswa pada kelas kontrol yang mengikuti pembelajaran dengan model konvensional.

Deskripsi kemandirian belajar matematis siswa untuk kelas eksperimen dan kontrol disajikan pada Tabel 4.

Tabel 4. Deskripsi Kemandirian Belajar Matematis Siswa (Posttest)

\begin{tabular}{lcc}
\hline \multicolumn{1}{c}{ Deskripsi } & Eksperimen & Kontrol \\
\hline Nilai maksimum & 110 & 110 \\
Nilai minimum & 85 & 80 \\
Nilai maksimum ideal & 120 & 120 \\
Nilai minimum ideal & 24 & 24 \\
Rata-rata & 95,95 & 94,48 \\
Simpangan baku & 7,83 & 6,95 \\
Jumlah siswa & 31 & 31 \\
\hline
\end{tabular}

Tabel 4 menginformasikan bahwa rata-rata skor skala kemandirian belajar pada kelas eksperimen lebih tinggi dibandingkan dengan kelas kontrol. Hal tersebut menunjukkan bahwa setelah mengikuti pembelajaran dengan pendekatan PBL kemandirian belajar siswa lebih baik dibandingkan siswa yang hanya mengikuti pembelajaran dengan pendekatan konvensional.

Tabel 5 menyajikan data perbandingan sebaran jumlah siswa pada kelas eksperimen dan kontrol berdasarkan kategori kemandirian belajar matematis.

Tabel 5. Sebaran Kemandirian Belajar Matematis Siswa

\begin{tabular}{lccc} 
& \multirow{2}{*}{ Kategori } & \multicolumn{2}{c}{ Banyak Siswa } \\
\cline { 2 - 4 } & & Eksperimen & Kontrol \\
\hline Sangat tinggi & 15 & 10 \\
Tinggi & 15 & 20 \\
Sedang & & 1 & 1 \\
Rendah & Total & - & - \\
& & 31 & 31 \\
\hline
\end{tabular}

Tabel 5 menunjukkan bahwa sebagian besar kemandirian belajar siswa pada kelas eksperimen dan kontrol berada pada kategori tinggi. Jumlah siswa dengan kategori kemandirian tinggi dan sangat tinggi pada kelas eksperimen lebih banyak dibandingkan kelas kontrol. Adapun rata-rata skor siswa berdasarkan tiap aspek kemandirian belajar matematis ditampilkan pada Tabel 6 .

Tabel 6. Skala Kemandirian Siswa Tiap Aspek

\begin{tabular}{lccc}
\hline \multicolumn{1}{c}{ Aspek } & Skor Ideal & Eksperimen & Kontrol \\
\hline Personal Atribut & 55 & $44,52(81 \%)$ & $42,10(77 \%)$ \\
Processes & 40 & $33,29(83 \%)$ & $31,77(79 \%)$ \\
Learning context & 25 & $19,85(77 \%)$ & $18,87(76 \%)$ \\
\hline
\end{tabular}

Tabel 6 menunjukkan bahwa rata-rata kemandirian belajar siswa kelas eksperimen untuk setiap aspek kemandirian belajar lebih tinggi dibandingkan kelas kontrol. Dengan demikian, kemandirian belajar siswa yang mengikuti pembelajaran dengan pendekatan PBL, jika ditinjau dari setiap aspeknya lebih baik dari pada kemandirian belajar siswa yang hanya mengikuti pembelajaran secara konvensional.

\section{Efektivitas PBL Ditinjau dari Keterampilan Pemecahan Masalah dan Kemandirian Belajar}

Dari hasil penelitian diperoleh rata-rata kemampuan pemecahan masalah matematis kelas eksperimen dan kelas kontrol berturut-turut 84,12 dan 77,27. Untuk menguji apakah pencapaian tersebut signifikan efektif atau tidak maka dilakukan one sample t test. Adapun hipotesis statistik yang akan diuji yaitu sebagai berikut.

$\mathrm{H}_{0}: \mu \leq 75$

$\mathrm{H}_{1}: \mu>75$

Dari hasil uji one sample $t$ test untuk kelas eksperimen diperoleh nilai $t_{\text {hitung }}=4,129$ dan $t_{\text {tabel }}=$ 2,054 dengan $p$-value $=0,000$. Karena $\mathrm{t}_{\text {hitung }}>\mathrm{t}_{\text {tabel }}$ dan $p$-value $<0,05$ maka $\mathrm{H}_{0}$ ditolak. Dengan kata 
lain, rata-rata kemampuan pemecahan masalah matematis pada kelas eksperimen mencapai di atas ketuntasan minimal yaitu 75. Dengan demikian dapat disimpulkan bahwa penerapan model PBL efektif ditinjau dari keterampilan pemecahan masalah siswa. Hal ini diperkuat dengan adanya 27 siswa $(87,09 \%)$ memperoleh nilai kemampuan pemecahan masalah $\geq 75$ dari jumlah keseluruhan 31 siswa. Jadi dapat disimpulkan bahwa proporsi siswa yang tuntas belajar $>85 \%$, yang berarti kelas eksperimen mencapai ketuntasan yang diinginkan yaitu telah mencapai ketuntasan klasikal.

Dari hasil penelitian diperoleh rata-rata skor kemandirian belajar kelas eksperimen dan kelas kontrol berturut-turut 95,95 dan 94,48. Untuk menguji apakah pencapaian tersebut signifikan efektif atau tidak maka dilakukan one sample t test. Adapun hipotesis statistik yang akan diuji yaitu sebagai berikut.

$\mathrm{H}_{0}: \mu \leq 90$

$\mathrm{H}_{1}: \mu>90$

Dari hasil uji one sample $t$ test untuk kelas eksperimen diperoleh nilai $t_{\text {hitung }}=4,220$ dan $t_{\text {tabel }}=$ 2,045 dengan $p$-value $=0,000$, karena $\mathrm{t}_{\text {hitung }}>\mathrm{t}_{\text {tabel }}$ dan $p$-value $<0,05$ maka $\mathrm{H}_{0}$ ditolak. Hasil uji tersebut menunjukkan bahwa kemandirian belajar siswa kelas eksperimen berada di atas skor 90. Dengan demikian dapat disimpulkan bahwa penerapan PBL dalam pembelajaran matematika efektif ditinjau dari kemandirian belajar matematis siswa. Hal ini diperkuat juga dengan adanya 30 siswa $(96,7 \%)$ memperoleh skor kemandirian belajar $\geq 90$ dari jumlah keseluruhan 31 siswa.

\section{Perbandingan Efektivitas PBL dan Pembelajaran Konvensional (Eksperimen vs. Kontrol)}

Perbandingan efektivitas antara penerapan model PBL dan pembelajaran konvensional dilakukan untuk mengetahui apakah PBL lebih efektif dibandingkan pembelajaran konvensional ditinjau dari keterampilan pemecahan masalah dan kemandirian belajar matematis siswa. Untuk menguji hal tersebut digunakan uji MANOVA. Salah satu persyaratan yang harus dipenuhi untuk melakukan uji MANOVA tersebut adalah kedua variabel terikat (keterampilan pemecahan masalah dan kemandirian belajar) berkorelasi secara signifikan. Berdasarkan hasil uji korelasi Pearson diperoleh nilai $r=0,432$ dengan nilai $p$-value $=0,018$. Dari hasil tersebut dapat disimpulkan bahwa terdapat hubungan yang signifikan antara keterampilan pemecahan masalah dan kemandirian belajar matematis, sehingga uji MANOVA dapat dilakukan.

Untuk mengetahui apakah kemampuan awal siswa pada kelas eksperimen dan kontrol sama, maka data hasil pretest dianalisis terlebih dahulu menggunakan uji MANOVA. Hasil uji kesamaan vektor rata-rata kemampuan awal siswa (keterampilan pemecahan masalah dan kemandirian belajar) kelas eksperimen dan kontrol disajikan pada Tabel 7.

Tabel 7. Hasil Uji Kesamaan Vektor Rata-Rata Kemampuan Awal

\begin{tabular}{rccccc}
\hline Effect & Value & $F$ & Hypotesis $d f$ & Error $d f$ & $p$-value \\
\hline Wilk's Lambda & 0,851 & 5,167 & 2,000 & 59,00 & 0,09 \\
\hline
\end{tabular}

Tabel 7 menunjukkan bahwa pada uji MANOVA diperoleh nilai $p$-value untuk kriteria Wilk's Lambda yaitu sebesar 0,09 . Nilai tersebut $>0,05$, sehingga dapat disimpulkan bahwa tidak terdapat perbedaan signifikan keterampilan pemecahan masalah dan kemandirian belajar matematis awal siswa pada kelas PBL (eksperimen) dan kelas konvensional (kontrol). Selanjutnya, untuk melihat apakah terdapat perbedaan efektivitas penerapan pendekatan PBL dan konvensional ditinjau dari kemampuan pemecahan masalah dan kemandirian belajar, maka data hasil posttest akan dianalisis. Hasil uji MANOVA untuk data posttest disajikan pada Tabel 8.

Tabel 8. Hasil Uji Kesamaan Vektor Rata-Rata Setelah Perlakuan

\begin{tabular}{cccccc}
\hline Effect & Value & $F$ & Hypotesis $d f$ & Error $d f$ & $p$-value \\
\hline Wilk's Lambda & 0,874 & 4,259 & 2,000 & 59,000 & 0,019 \\
\hline
\end{tabular}

Tabel 8 menunjukkan bahwa pada uji MANOVA diperoleh nilai $p$-value untuk kriteria Wilk's Lambda yaitu sebesar 0,019 . Nilai tersebut $<0,05$, sehingga dapat disimpulkan bahwa terdapat perbedaan signifikan antara kelas yang menerapkan pendekatan PBL dan konvensional ditinjau dari keterampilan pemecahan masalah dan kemandirian belajar matematis siswa. Perbedaan rata-rata ini menunjukkan adanya perbedaan efektivitas pendekatan PBL dan pembelajaran konvensional. Dilihat dari rata-ratanya, keterampilan pemecahan masalah matematis dan kemandirian belajar pada kelas yang 
menerapkan PBL lebih tinggi daripada kelas yang hanya menerapkan pembelajaran konvensional. Dengan demikian dapat disimpulkan bahwa PBL lebih efektif dari model konvensional ditinjau dari keterampilan pemecahan masalah dan kemandirian belajar matematis.

\section{Pembahasan}

Penelitian ini dilakukan untuk membuktikan empat hipotesis. Berdasarkan hasil analisis yang telah dilakukan diperoleh hasil yaitu: (1) PBL efektif ditinjau dari keterampilan pemecahan masalah; (2) PBL efektif ditinjau dari kemandirian belajar; (3) terdapat hubungan signifikan antara kemampuan pemecahan masalah dengan kemandirian belajar matematis siswa; dan (3) PBL lebih efektif dibandingkan pembelajaran konvensional ditinjau dari keterampilan pemecahan masalah dan kemandirian belajar matematis. Keterampilan pemecahan masalah matematis dalam penelitian ini adalah keterampilan siswa untuk meyelesaikan masalah matematis yang terkait dengan empat aspek, yaitu memahami masalah, merencanakan penyelesaian, menyelesaikan masalah sesuai rencana, dan interpretasi/pemaknaan hasil.

Hasil penelitian menunjukkan bahwa siswa pada kelas eksperimen dengan PBL memiliki ratarata skor keterampilan pemecahan masalah matematis lebih tinggi dibandingkan siswa pada kelas kontrol yang mengikuti pembelajaran dengan model konvensional. Apabila dilihat tiap aspeknya ternyata rata-rata skor tiap aspek dari siswa yang mengikuti PBL lebih tinggi dari siswa yang mengikuti pembelajaran konvensional. Rata-rata kemampuan pemecahan masalah matematis tiap aspek jika diurutkan dari yang tertinggi, diperoleh rata-rata tertinggi pada aspek keterampilan merencanakan penyelesaian, yaitu $2,81(93,5 \%)$, dan rata-rata terendah pada aspek interpretasi/pemaknaan hasil, yaitu $2,23(74,33 \%)$.

Berikut ini disajikan beberapa contoh hasil pekerjaan siswa pada tes kemampuan pemecahan masalah matematis sebagai bukti empiris pembuktian teori dalam penelitian.

Soal 1:

Wanti diminta ibunya ke pasar untuk membeli dua jenis ikan, Kembung dan Kakap. Ibunya hanya memberi uang sebanyak Rp40.000,00 dan semuanya harus dibelikan kedua jenis ikan tersebut. Pada salah satu tempat penjualan ikan, Wanti menemukan harga sebagai berikut.

a. Harga 5 ekor ikan kembung dan 2 ekor ikan kakap adalah Rp17.000,00.

b. Harga 6 ekor ikan kembung dan 3 ekor ikan kakap adalah Rp24.000,00.

Jika masing-masing jenis ikan sama besar, berapa banyak ikan dari kedua jenis yang dapat dibeli Wanti?

Contoh jawaban siswa dalam menyelesaikan Soal 1 disajikan pada Gambar 1.

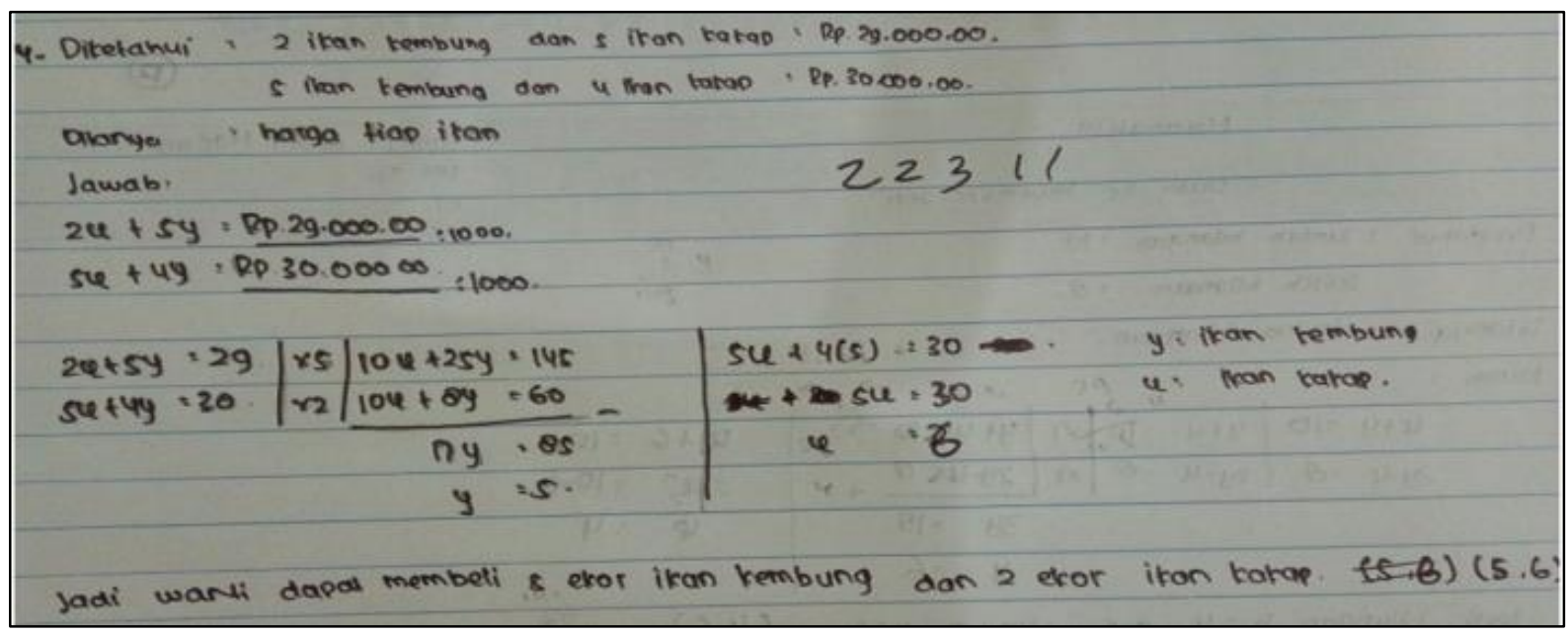

Gambar 1. Contoh Jawaban Siswa Kelas Eksperimen (Kategori Tinggi)

Dari jawaban siswa pada Gambar 1, diperoleh informasi bahwa siswa mampu memahami masalah dengan baik juga mampu merencanakan penyelesaian dengan baik. Hal ini diindikasikan dari siswa menuliskan model matematika dengan baik dan benar serta memilih metode gabungan (eliminasi dan substitusi). Namun siswa melakukan kesalahan dalam menyelesaikaan masalah sesuai rencana, yaitu kesalahan dalam perhitungan matematis, sehingga siswa memperoleh hasil yang salah. Karena hasil yang diperoleh salah, sehingga siswa juga salah dalam menginterpretasikan hasil. Hal ini sejalan 
dengan hasil penelitian Fatimah dan Khotimah (2015) bahwa salah satu penyebab kesulitan siswa dalam menyelesaikan soal cerita pada materi sistem persamaan linier adalah siswa kurang teliti dalam melakukan perhitungan matematis.

Keterampilan interpretasi/pemaknaan hasil lebih rendah dibandingkan dengan kemampuan lainnya. Hal ini terlihat dari beberapa jawaban siswa yang tidak menginterpretasikan hasil dan beberapa siswa salah dalam menginterpetasikan hasil, yang disebabkan karena siswa salah dalam melakukan perhitungan. Gambar 2 menyajikan hasil pekerjaan siswa yang menunjukkan bahwa siswa sebenarnya mampu menginterpretasikan hasil.

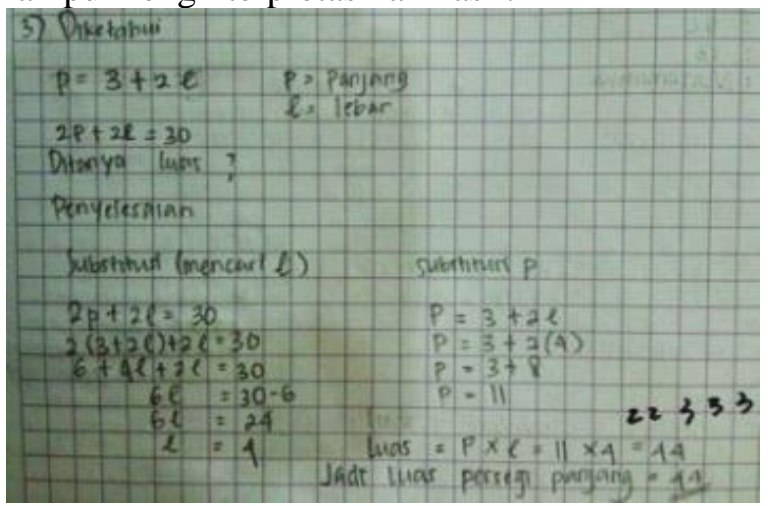

(a)

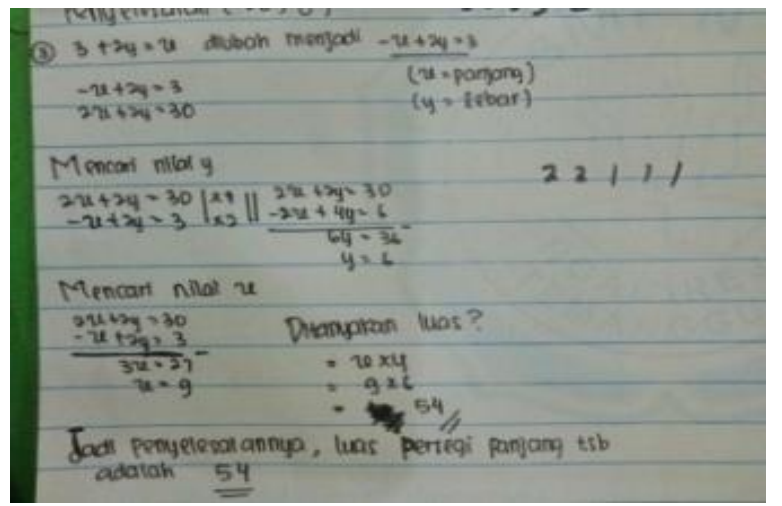

(b)

Gambar 2. (a) Interpretasi Jawaban Benar, (b) Interpretasi Jawaban Salah

Banyak siswa (terutama siswa dengan kategori kemampuan pemecahan masalah matematis yang sangat tinggi dan tinggi) yang menginterpretasikan hasil dengan benar seperti tampak pada Gambar 2 (a). Akan tetapi ada beberapa siswa yang salah mengintrepretasikan hasil (terutama siswa dengan kategori kemampuan pemecahan masalah yang sedang dan rendah). Hal ini disebabkan oleh perhitungan yang salah seperti yang tampak pada Gambar 2 (b). Dari beberapa temuan tersebut, dapat disimpulkan bahwa tingkat akurasi perhitungan matematis siswa masih rendah, sehingga jawaban yang diperoleh juga keliru.

Pada pembelajaran dengan pendekatan PBL, di awal pembelajaran siswa disajikan masalahmasalah, kemudian melalui pemecahan masalah tersebut siswa belajar keterampilan-keterampilan yang lebih mendasar (Siburian, 2010). Pendapat yang kurang lebih serupa menyatakan bahwa tahap pertama pada PBL, yaitu orientasi siswa pada masalah (Arends, 2008). PBL yang diawali dengan penyajian dan pembahasan masalah, menjadikan siswa terbiasa untuk memahami masalah. Selanjutnya, siswa juga terlibat aktif mencari solusi, sehingga siswa semakin terbiasa dalam menyelesaikan masalah. Adanya hal-hal tersebut, disinyalir menjadi penyebab PBL efektif untuk meningkatkan keterampilan pemecahan masalah matematis.

Hasil penelitian ini sesuai dengan hasil penelitian Setiawan et al. (2014) yang menyimpulkan bahwa aktivitas siswa dalam PBL berpengaruh positif terhadap keterampilan pemecahan masalah siswa. Hasil penelitian ini juga serupa dengan hasil penelitian Fatimah (2009) yang menunjukkan bahwa keterampilan pemecahan masalah dengan menerapkan PBL lebih baik dibanding dengan pembelajaran konvensional. Hasil penelitian ini juga memperkuat temuan penelitian Angkotasan (2013) yang menunjukkan bahwa PBL efektif ditinjau dari kemampuan pemecahan masalah siswa. Selain itu, hasil penelitian ini juga memperkuat temuan penelitian Jailani, Sugiman, dan Apino (2017), dimana dalam penelitian tersebut ditemukan bahwa PBL efektif untuk meningkatkan keterampilan berpikir tingkat tinggi siswa, dimana pemecahan masalah merupakan bagian tak terpisahkan dalam aktivitas berpikir tingkat tinggi.

Disamping keterampilan pemecahan masalah matematis, dalam penelitian ini juga meninjau tentang kamandirian belajar. Kemandirian belajar dalam penelitian ini berupa skor yang diperoleh dari skala kemandirian meliputi aspek personal attributes, processes, dan learning context. Aspek processes meliputi perencanaan, motivasi, dan evaluasi, sedangkan aspek personal atribut. Apabila dibandingkan rata-rata skor kemandirian belajar antara kelas PBL dan pembelajaran konvensional, diperoleh bahwa rata-rata skor kemandirian belajar kelas eksperimen lebih tinggi. Hal ini menunjukkan bahwa PBL lebih efektif dari pembelajaran konvensional ditinjau dari kemandirian belajar matematis siswa. 
Arends (2008) menyatakan bahwa pembelajaran PBL memiliki lima fase, yaitu orientasi siswa pada masalah, mengorganisasi siswa untuk belajar, membimbing penyelidikan individual maupun kelompok, mengembangkan dan menyajikan hasil karya, menganalisis dan mengevaluasi. Langkah ketiga dari pembelajaran dengan PBL adalah membimbing penyelidikan individual maupun kelompok. Selama fase ini siswa harus menyelidiki, melihat hubungan, memanfaatkan buku ataupun sumber belajar. Kegiatan pembelajaran pada fase ini sangat menuntut kemandirian siswa. Selain itu, menyelidiki, melihat hubungan, memanfaatkan buku atau sumber belajar merupakan sub aspek dari personal atribut yang merupakan salah satu aspek kemandirian belajar. Hal tersebut disinyalir menjadi penyebab PBL lebih efektif untuk meningkatkan kemandirian belajar siswa.

Langkah terakhir dari PBL adalah menganalisis dan mengevaluasi. Pada fase ini siswa akan menganalisis dan mengevaluasi hasil pekerjaan kelompok, hasil pekerjaan kelompok lain, juga evaluasi dan penekanan hal penting dari guru. Dengan adanya evaluasi diakhir pembelajaran siswa akan mengetahui kekurangan dan kelebihan pekerjaan yang telah dilakukan. Evaluasi pembelajaran merupakan sub aspek dari processes yang merupakan aspek dari kemandirian belajar, sehingga fase tersebut juga berkontribusi bagi peningkatan kemandirian belajar matematis siswa.

Hasil penelitian ini sesuai dengan pendapat Killen (2009) yang menyatakan bahwa dalam PBL siswa yang mampu menyelesaikan tugas dan menemukan pengetahuan yang baru dari dirinya sendiri, akan memiliki kepuasan yang besar. Hal ini dapat dikataan bahwa melalui PBL siswa memiliki keyakinan diri (self-efficacy) yang merupakan aspek dari kemandirian belajar. Hal ini sejalan dengan penelitian Lubis (2015) yang menyatakan bahwa peningkatan keterampilan pemecahan masalah dan kemandirian belajar pada PBL lebih tinggi dari pembelajaran konvensional. Hasil penelitian ini juga bersesuaian dengan pendapat Arends (Suprihatiningrum, 2016, p.215) bahwa PBL merupakan pendekatan pembelajaran yang mengembangkan keterampilan berpikir tingkat lebih tinggi, mengembangkan kemandirian dan percaya diri. Pendapat yang hampir sama disampaikan Riyanto (2010, pp.307-308) yang menyatakan bahwa PBL memfokuskan pada siswa dengan mengarahkan siswa menjadi pembelajar yang mandiri dan terlibat langsung secara aktif dalam pembelajaran berkelompok.

Hasil penelitian juga menunjukkan bahwa terdapat hubungan yang signifikan antara kemampuan pemecahan masalah dan kemandirian belajar matematis siswa $(r=0,432, p$-value $=0,018)$. Hal tersebut menunjukkan bahwa siswa yang mempuyai kemampuan pemecahan masalah yang tinggi muncul keyakinan dalam dirinya bahwa dia mampu untuk menyelesaikan tugas-tugas yang diberikan sehingga kemandirian belajarnya meningkat. Begitu pula sebaliknya, siswa yang mempunyai kemandirian belajar yang tinggi akan aktif menggunakan berbagai sumber belajar, menyelesaikan tugas-tugas yang diberikan, serta menyelesaikan soal-soal pemecahan masalah. Temuan tersebut sejalan dengan hasil penelitian Darma (2016) dan Ayu (2017) yang menyatakan bahwa terdapat hubungan yang signifikan antara kemandirian belajar dengan kemampuan pemecahan masalah matematis, sehingga semakin tinggi kemandiran belajar seseorang, semakin tinggi pula keterampilan pemecahan masalahnya.

\section{SIMPULAN}

Berdasarkan hasil penelitian dan pembahasan, dapat disimpulkan beberapa hal. Pertama, PBL efektif ditinjau dari keterampilan pemecahan masalah matematis siswa. Kedua, PBL efektif ditinjau dari kemandirian belajar matematis siswa. Ketiga, terdapat hubungan positif dan signifikan antara keterampilan pemecahan masalah dengan kemandirian belajar matematis siswa. Keempat, terdapat perbedaan efektivitas antara PBL dengan pembelajaran konvensional ditinjau dari kemampuan pemecahan masalah dan kemandirian belajar siswa, dimana keterampilan pemecahan masalah dan kemandirian belajar siswa pada pembelajaran dengan PBL lebih tinggi dibandingkan dengan pembelajaran konvensional. Hasil penelitian juga mengimplikasikan bahwa PBL dapat digunakan sebagai salah satu alternatif bagi guru untuk meningkatkan keterampilan pemecahan masalah maupun kemandirian belajar siswa, terutama dalam pembelajaran matematika. Selain itu, bagi peneliti lainnya disarankan untuk melakukan penelitian serupa dengan menggunakan populasi dan sampel yang lebih besar, sehingga dapat dilakukan generalisasi yang lebih luas lagi terkait dengan efektivitas PBL dalam meningkatkan hasil belajar siswa dalam pembelajaran matematika. 


\section{DAFTAR PUSTAKA}

Angkotasan, N. (2013). Model PBL dan cooperative learning tipe TAI ditinjau dari aspek kemampuan berpikir reflektif dan pemecahan masalah matematis. Pythagoras: Jurnal Pendidikan Matematika, 8(1), 92-100. doi: https://doi.org/10.21831/pg.v8i1.8497

Arends, R. I. (2008). Learning to teach: Belajar untuk mengajar (7th ed.) (H. P. Soetjipto \& M. Soetjipto, trans.). Yogyakarta: Pelajar. (Original work published 2008).

Ayu, N. P. (2017). Hubungan kemampuan penalaran dan kemandirian belajar terhadap pemecahan masalah matematika pada siswa kelas VIII SMP negeri di Kota Baubau Sulawesi Tenggara (Master's Thesis, Universitas Negeri Yogyakarta, Yogyakarta, Indonesia). Retrieved from https://eprints.uny.ac.id/52037/

Barrett, T. (2005). Understanding problem based learning. In T. Barrett, I. M. Labhrainn \& H. Fallon (Eds.), Handbook of Enquiry and problem-based learning: Irish case studies and international perspectives (pp. 13-25). Dublin: All Ireland Society for Higher Education (AISHE).

Chen, W. (2013). Teaching geometry through problem-based learning and creative design. Proceedings of the 2013 International Conference on Education and Educational Technologies, Department of Applied Mathematics Tunghai University, Taiwan.

Darma, Y. (2016). Hubungan kemandirian belajar terhadap kemampuan pemecahan masalah matematis mahasiswa calon guru matematika. Edukasi: Jurnal Pendidikan, 14(1), 169-178. doi: http://dx.doi.org/10.31571/edukasi.v14i1.294

Fatimah, F. (2009). Kemampuan komunikasi matematis dan pemecahan masalah melalui problem based learning. Jurnal Penelitian dan Evaluasi Pendidikan, 16(1), 249-259. doi: https://doi.org/10.21831/pep.v16i1.1116

Fatimah, N. P., \& Khotimah, R. P. (2015). Analisis kesulitan siswa dalam menyelesaikan soal cerita sistem persamaan dan pertidaksamaan linier di kelas X SMK Prawira Marta Kartasura tahun ajaran 2014/2015. Paper presented at the Seminar Nasional Pendidikan Matematika Universitas Muhammadyah Surakarta, Surakarta. Retrieved from https://publikasiilmiah.ums.ac.id/handle/ $11617 / 6134$ ?show=full

Hima, L. (2016). Penerapan model pembelajaran problem based learning ditinjau dari kemampuan komunikasi matematik. Jurnal Ilmiah Pendidikan Matematika, 4(2), 111-121. doi: http://doi.org/10.25273/jipm.v4i2.845

Imandala, I., Li, R., \& Supriyadi, A. (2019). Analysis of problem-based learning models by typology of knowledge Pollock and Cruz (1999). International Journal of Education and Learning, 1(1), 111. doi:https://doi.org/10.31763/ijele.v1i1.12

Jailani, J., Sugiman, S., \& Apino, E. (2017). Implementing the problem-based learning in order to improve the students' HOTS and characters. Jurnal Riset Pendidikan Matematika, 4(2), 247-259. doi: https://doi.org/10.21831/jrpm.v4i2.17674

Kementerian Pendidikan dan Kebudayaan Republik Indonesia. (2011). Survei internasional TIMSS. Jakarta: Kementerian Pendidikan dan Kebudayaan Republik Indonesia.

Kementerian Pendidikan dan Kebudayaan Republik Indonesia. (2016). Peraturan Menteri Pendidikan dan Kebudayaan Republik Indonesia Nomor 21 Tahun 2016 tentang Standar Isi Pendidikan Dasar dan Menengah.

Killen, R. (2009). Effective teaching strategies: Lesson from research and practice (5th ed.). Newcastle, UK: Social Science Press.

Lubis, S., Surya, E., \& Minarni, A. (2015). Peningkatan kemampuan pemecahan masalah matematika dan kemandirian belajar siswa SMP melalui model pembelajaran berbasis masalah. Paradikma Jurnal Pendidikan Matematika, 8(3). doi: https://doi.org/10.24114/paradikma.v8i3.3365

NCTM. (2000). Principles and standars for school mathematics. Reston, VA: Author.

OECD. (2014). PISA 2012 results in focus: What 15-year-olds know and what they can do with what they know. Retrieved from http://www.oecd.org/pisa/keyfindings/pisa-2012-results-overview.pdf 
Presiden Republik Indonesia (2003). Undang-Undang Republik Indonesia Nomor 20 Tahun 2003 tentang Sistem Pendidikan Nasional. Retrieved from https://kelembagaan.ristekdikti.go.id/wpcontent/ uploads/2016/08/UU_no_20_th_2003.pdf

Puspendik. (2015). Penguasaan materi soal matematika ujian nasional SMP/MTs tahun pelajaran 2014/2015. Jakarta: Balitbang Kemendikbud.

Riyanto, Y. (2010). Paradigma pembelajaran sebagai referensi bagi pendidik dalam implementasi pembelajaran yang efektif dan berkualitas. Jakarta: Kencana.

Setiawan, D., Waluya, B., Mashuri, M. (2014). Keefektifan PBL berbasis nilai karakter berbantuan CD pembelajaran terhadap kemampuan pemecahan masalah materi segiempat. Unnes Journal of Mathematics, 3(1), 15-20. Retrieved from https://journal.unnes.ac.id/sju/index.php/ujme/ article/view/3431

Siburian, J. (2010). Model pembelajaran sains. Jambi: Universitas Jambi.

Sugiman, S. (2013). Student's competency in solving and creating mathematical problem in pre-service training program. Jurnal Teknologi (Social Sciences), 63(2), 117-121. doi: https://doi.org/10.11113/jt.v63.2021

Suprihatiningrum, J. (2016). Strategi pembelajaran teori dan aplikasi. Yogjakarta: Ar-Ruzz Media.

Wijaya, A. A., \& Masriyah, M. (2013).Analisis kesalahan siswa dalam menyelesaikan soal cerita materi sistem persamaan linear dua variabel. MATHEdunesa, 2(1). Retrieved from https://jurnalmahasiswa.unesa.ac.id/index.php/mathedunesa/article/view/1453 